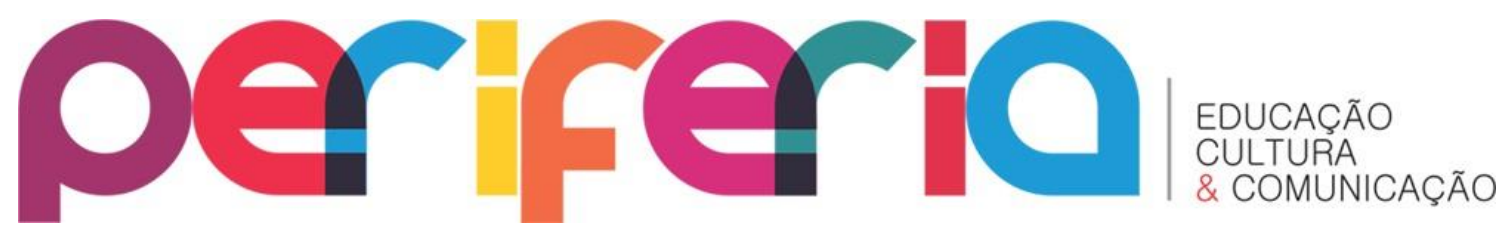

ISSN:1984-9540

DOI: $10.12957 /$ periferia. 2020.44346

\title{
O TRABALHO COM GÊNERO MEMES EM SALA DE AULA: POTENCIALIDADES PARA A FORMAÇÃO DO LEITOR
}

\author{
João Miller Da Silva ${ }^{1}$ \\ Stela Mara Botelho ${ }^{2}$ \\ Helena Maria Ferreira ${ }^{3}$
}

\section{Resumo}

0 presente artigo elege como objeto de reflexão as potencialidades do gênero memes para a formação do leitor. Essa pesquisa teve por intento compilar estudos que versam sobre o gênero memes - uma manifestação cultural que tem recebido destaque nos últimos tempos na internet. Assim, essa pesquisa tem como objetivo: (i) apresentar um estudo sobre o gênero memes e destacar o que estes trabalhos discutem sobre suas aplicações em sala de aula, e (ii) analisar, a partir da perspectiva do gênero do discurso memes, o conteúdo temático, o plano composicional e o estilo de linguagem do gênero memes. Para a consecução do objetivo proposto foi realizado um estudo bibliográfico, com vistas a fundamentar teoricamente o trabalho embasado por Bakhtin (2003), Braga (2018), Horta (2015), Santos (2013), entre outros. Além da pesquisa teórica, este trabalho apresenta os resultados de uma análise de três memes em vídeo. Tais análises apresentam um foco direcionado para o conteúdo temático, o plano composicional e o estilo do memes. Espera-se que as reflexões decorrentes deste trabalho possam iluminar o percurso formativo de professores, potenciais leitores, uma vez que o trabalho com memes em sala de aula, além de mobilizar o interesse do aluno para a aprendizagem, pode favorecer a ampliação de várias habilidades relacionadas aos multiletramentos.

Palavras-chave: Gêneros Discursivos; Memes; Multimodalidade.

\footnotetext{
${ }^{1}$ Possui Graduação em Letras Português/Inglês e suas Literaturas pela Universidade Federal de Lavras. Participante do grupo de estudos GEPLE -Grupo de Estudos e Pesquisa em Leitura e Escrita da Universidade Federal de Lavras. Mestrando em Letras com foco na linha de Estudos analítico-descritivos de língua/linguagem e suas tecnologias na Universidade Federal de Lavras. ORCID iD: https://orcid.org/0000-0002-0743-689X. E-mail: millersilvanep@hotmail.com

2 Possui Graduação em Letras Português/Inglês e suas Literaturas pela Universidade Federal de Lavras. E-mail: stelamara55@hotmail.com

${ }_{3}^{3}$ Possui graduação em Letras pelo Centro Universitário de Patos de Minas (1993), graduação em Letras (Português/Espanhol) pela Universidade de Uberaba (2010) e graduação em Pedagogia pela Universidade Federal de Uberlândia (2013). Possui Curso de Especialização em Linguística pelo Centro Universitário de Patos de Minas, Mestrado em Linguística pela Universidade Federal de Uberlândia (1998) e doutorado em Linguística Aplicada e Estudos da Linguagem pela Pontifícia Universidade Católica de São Paulo (2008). Professora adjunta da Universidade Federal de Lavras. ORCID iD: https://orcid.org/0000-0002-8749-5426. E-mail: helenaferreira@hotmail.com
}

Periferia, v. 12, n. 3, p. 302-321, set./dez. 2020 


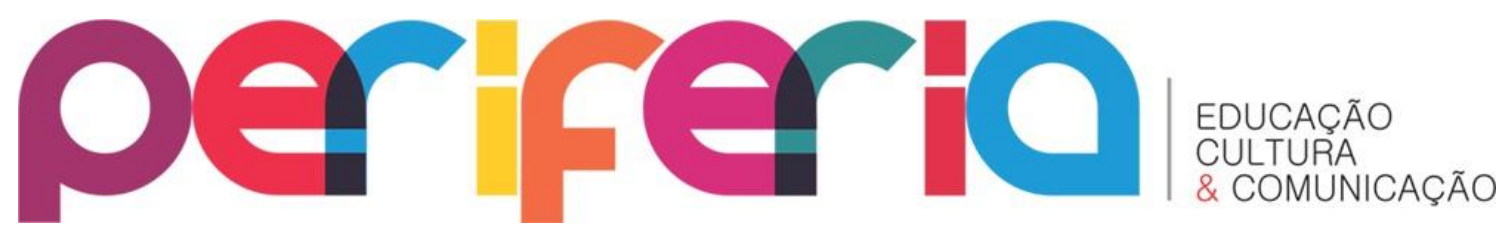

\title{
THE WORK WITH GENRE MEMES IN THE CLASSROOM: POTENTIALITIES FOR A READER TRAINING
}

\begin{abstract}
The present study elects as an object of reflection the potentialities of the memes genre for the formation of the reader. This research had as intent to compile studies that deal with the genre meme -a cultural manifestation that has been highlighted in recent times on the Internet. Thus, this research aims to: (i) present a study on the genre memes and highlight the self these papers discuss about their applications in the classroom, and (ii) analyze, from the perspective of the genre of discourse, the thematic content, the compositional plan and the style of Language of the meme. To achieve the proposed objective, a bibliographical study was carried out, with a view to theoretically substantiate the study based on Bakhtin (2003), Braga (2018), Horta (2015), Santos (2013), among others. In addition, this paper presents the results of an analysis of three video memes. Such propositions have a focused focus on the thematic content, the compositional plane, and the meme style. It is hoped that as reflections is a task that allows to illuminate the trajectory of the teachers, the pedagogical potentialities, since the work with the genre memes the classroom, besides mobilizing the student's interest for a learning, can favor an extension of multilevel skills.
\end{abstract}

Keywords: Discursive genre; Memes; Multimodality.

Introdução

0 presente artigo elege como objeto de discussão as potencialidades do gênero memes ${ }^{4}$ para a formação do leitor. As novas tecnologias da informação intensificaram, no contexto social, a conjugação de diferentes semioses em uma mesma produção, o que ocasionou uma maior disseminação dos textos denominados de multissemióticos, ou seja, que combinam imagens em movimentos, sons, cores, diagramações, entre outros. O memes tornou- se

\footnotetext{
${ }^{4}$ Memes advém da abreviação mimeme de origem grega, que significa imitação. Eles têm a capacidade de atingir milhares de internautas em poucos minutos, e além de possuir uma linguagem acessível, são criados a partir de imagens icônicas. 0 termo memes foi cunhado por Richard Dawkins, em sua obra o gene egoísta, que foi publicado em 1976.
}

Periferia, v. 12, n. 3, p. 302-321, set./dez. 2020 


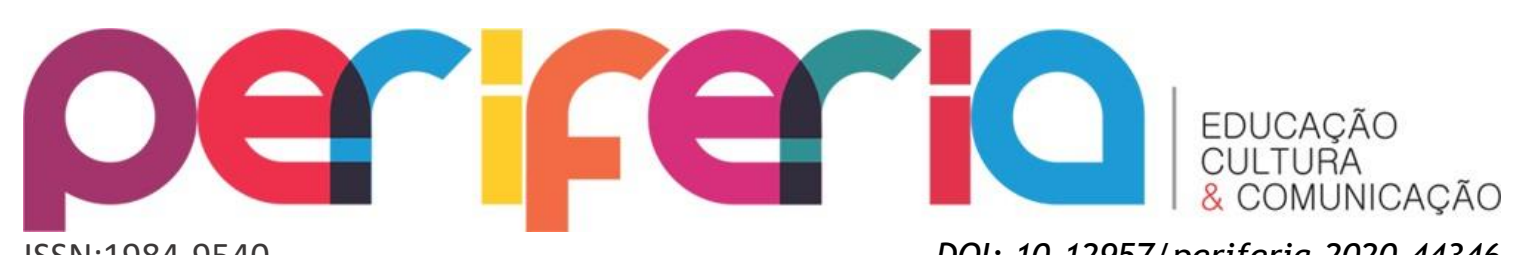

ISSN:1984-9540

DOI: 10.12957/periferia.2020.44346 conhecido e utilizado na internet, por meio de um fenômeno de viralização de uma informação a partir, da imagem de figura fotográfica, frase, ideia, música, vídeo ou qualquer elemento que apresente um conteúdo irônico e humorístico que se replique entre vários internautas. Alguns questionamentos ainda são muito recorrentes, tais como: Como trabalhar o gênero discursivo memes de forma reflexiva? Quais são as potencialidades do trabalho com esse gênero em aulas de língua portuguesa? Assim, esta pesquisa tem como proposta: (i) apresentar um estudo sobre o gênero memes e destacar o que estes trabalhos discutem sobre suas aplicações em sala de aula, e (ii) analisar, a partir da perspectiva do gênero do discurso memes, o conteúdo temático, o plano composicional e o estilo de linguagem do gênero memes.

Ao eleger o memes como objeto de discussão, é relevante pontuar que esse gênero passa a ter maior circulação, a partir do advento das tecnologias digitais da informação e comunicação (TDIC), irrompendo uma nova forma de abordar questões sociais. Nesse sentido, o memes passa a ser concebido como "uma forma multimodal, paródica humorista e crítica de dialogar de disseminar pontos de vistas" (SILVA, 2018, p.15).

Assim, considerando o memes como um gênero discursivo que integra o cotidiano social, é substancial a inserção desse tipo de texto nas práticas de ensino, com vistas a explorar as suas potencialidades pedagógicas, seja para proporcionar aos estudantes o desenvolvimento de habilidades multissemióticas de leitura e escrita, ou para formar cidadãos críticos e reflexivos.

Nessa direção, o tema se justifica pela possibilidade de um ensino que se desloque da perspectiva formalista, recorrentemente, abordada no âmbito da sala de aula de língua portuguesa, que se concentra, predominantemente, nos estudos da gramática normativa tradicional. Nesse sentido, parte-se do pressuposto de que o trabalho com memes em sala de aula permite desenvolver um ensino pautado na dialogicidade e na dialética que se estabelece entre uso e reflexão.

Para o tratamento da temática proposta, buscou-se teorizar sobre o conceito de gênero discursivo, a caracterização do gênero memes, o trabalho com o gênero 


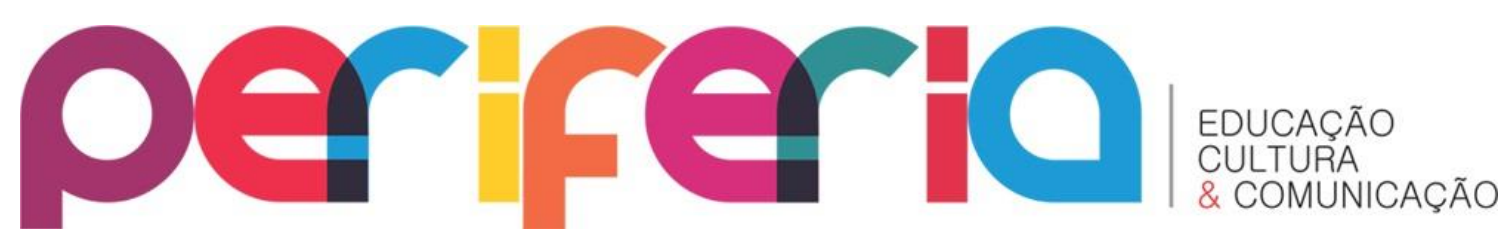

ISSN:1984-9540

DOI: $10.12957 /$ periferia.2020.44346

memes em sala de aula. Além da pesquisa teórica, este trabalho apresenta os resultados de uma análise de três memes em vídeo. Tais análises apresentam um foco direcionado para o conteúdo temático, o plano composicional e o estilo do memes. Esperamos que as reflexões decorrentes deste trabalho possa iluminar o percurso formativo de professores, potenciais leitores, uma vez que o trabalho com memes em sala de aula, além de mobilizar o interesse do aluno para a aprendizagem, pode favorecer a ampliação de várias habilidades relacionadas aos multiletramentos.

\section{Gêneros discursivos: o memes em questão}

Ao discutir gêneros discursivos Bakhtin (2003) postula, que todo e qualquer modo de comunicação, seja verbal ou não verbal, constitui-se pelo que se convencionou chamar de gêneros discursivos. Para o autor,

O emprego da língua efetua-se em forma de enunciados (orais e escritos) concretos e únicos, proferidos pelos integrantes desse ou daquele campo da atividade humana. Esses enunciados refletem as condições específicas e as finalidades de cada referido campo não só por seu conteúdo (temático) e pelo estilo da linguagem, ou seja, pela seleção dos recursos lexicais, fraseológicos e gramaticais da língua mas, acima de tudo, por sua construção composicional. Todos esses três elementos - o conteúdo temático, o estilo, a construção composicional - estão indissoluvelmente ligados no todo do enunciado e dão igualmente determinados pela especificidade de um determinado campo da comunicação. Evidentemente, cada enunciado particular é individual, mas cada campo de utilização da língua elabora seus tipos relativamente estáveis de enunciados, os quais denominamos gêneros do discurso. (BAKHTIN, 2003, p. 261-262)

Desse modo, pode-se constatar que os tipos estáveis, postulados por Bakhtin (2003), referem-se ao conjunto de enunciados que utilizamos para interagir em sociedade. Assim, funda-se o pressuposto dialógico, que incorpora o contexto verbal e o contexto extraverbal (aspectos situacionais, históricos e ideológicos). Um gênero se materializa em uma peculiar situação enunciativa concreta, por meio de elementos sociodiscursivos estabilizados nas e pelas interações ao longo da histórica. Caracterizar um gênero discursivo implica garantir o espaço do outro na dinâmica discursiva, que elucida as especificidades das esferas sociais nas quais esse gênero se constituiu.

O termo memes foi concebido por Richard Dawkins, em sua obra o gene egoísta, que foi publicado em 1976. Dawkins (2007) pontua que o gene é uma 


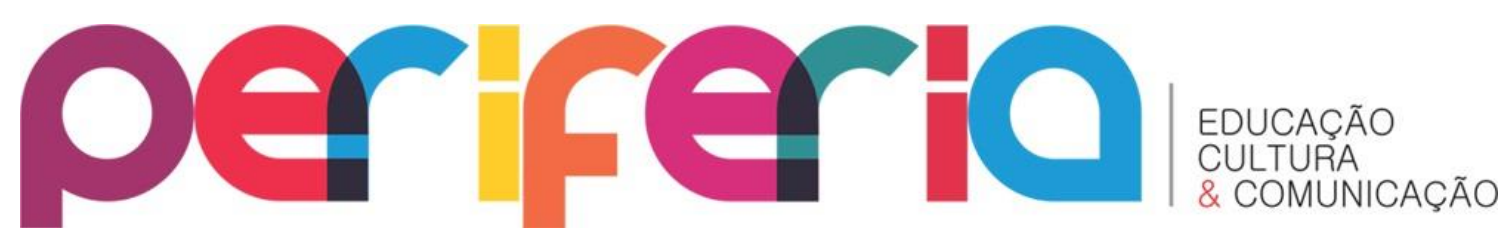

ISSN:1984-9540

DOI: $10.12957 /$ periferia.2020.44346

representação natural e biológica do ser humano, e que o meme (s) seria seu gene cultural, pois é uma unidade de informação que é capaz de se multiplicar, por meios de ideias e informações que se propaga de cérebro para cérebro, ou seja, de individuo para individuo.

De acordo com Dawkins (2007)

Exemplos de memes são melodias, ideias, slogans, as modas no vestuário, as maneiras de fazer potes ou de construir arcos. Tal como os genes se propagam no pool gênico saltando de corpo para corpo através dos espermatozoides ou dos óvulos, os memes também se propagam no pool de memes saltando de cérebro para cérebro (DAWKINS, 2007, p. 330).

O gênero memes é empregado nos estudos comunicacionais a partir do contexto de análise dinâmica da internet, faz-se necessário uma análise mais elaborada do termo e dessa maneira Dawkins (2007) reconhece que:

Ao que parece, a palavra "meme" está se mostrando, ela própria, um bom meme. É bastante usada hoje em dia e entrou, em 1988 na lista oficial de palavras a serem consideradas para as edições futuras do Oxford English dictionary. Isso aumenta ainda mais a minha preocupação em reafirmar que as minhas pretensões de discutir a cultura humana eram quase inexistentes, de tão modestas. As minhas verdadeiras pretensões - elas são reconhecidamente grandes - vão numa direção completamente diferente. Quero reivindicar um poder quase ilimitado para as entidades auto-replicadoras ligeiramente imperfeitas que surgirem em qualquer parte do universo (DAWKINS, 2007, p. 506).

A partir dos estudos de Dawkins que denota o meme como gene da cultura, Recuero (2007) desenvolveu um estudo sobre a aplicação desta forma de comunicação em web blogs propondo uma classificação dividindo os seguintes critérios: fidelidade da copia, longevidade e a fecundidade. Para que o meme estabeleça um grau de sobrevivência, eles devem possuir essas características que lhe dão o status de memes bem-sucedidos no espaço.

A primeira delas, a longevidade, diz respeito à capacidade de existência do meme, ou seja, quanto mais tempo o meme sobreviver, maior será sua chance de ser compartilhado (RECUERO, 2007).

Já a fecundidade diz respeito "a capacidade de difusão de um meme, isto é, a possibilidade de propagação ocupando espaço em veículos, quer sejam nossos cérebros ou qualquer outro suporte" (HORTA, 2018, p. 34). Vale destacar que um alto gral de fecundidade, não implica no alto grau de longevidade. 


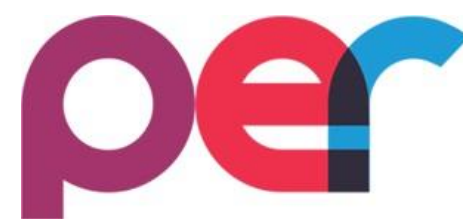

ISSN:1984-9540
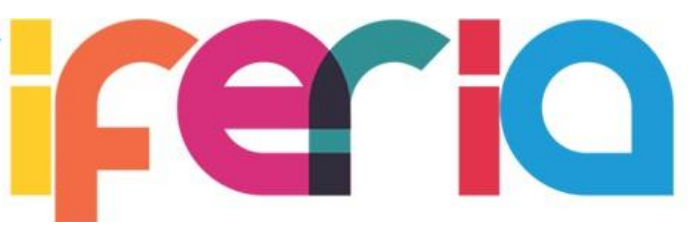

EDUCAÇÃO

CULTURA

\& COMUNICAÇÃO

DOI: 10.12957/periferia.2020.44346

Por fim, temos a fidelidade, que se refere à capacidade do memes de gerar cópias com maior semelhança ao memes original.

O gênero memes possui uma construção complexa, composta por múltiplas semioses, que demandam habilidades para o processo de produção de sentidos, uma vez que a produção apresenta-se muito atrelada à dimensão contextual. Para Bakhtin (1981, p. 76), a "linguagem é um fenômeno eminentemente social que se processa na e pela interação entre dois ou mais interlocutores", ou seja, toda a interação é realizada a partir de um discurso, em que a tipologia muda de acordo com a particularidade dos interlocutores e da forma como ocorre a interação (SILVA, 2016). Esse gênero evoca atenção pela dinamicidade, multimodalidade e elementos que vão além do humor e de sua animação (GUERREIRO, SOARES, 2016).

Para Silva, Francelino e Melo (2017, p. 178), o meme é considerado um gênero discursivo, pois

possui uma ancoragem em um espaço de criação e de recepção por sujeitos reais; está, pois, dialogicamente constituído das novas formas de interação do espaço virtual, sobretudo, daquelas presentes nas redes de comunicação existentes na internet, a exemplo do GIF. Ademais, possui os seus três componentes específicos apontados por Bakhtin, isto é, estruturalmente representado, demonstrando o conteúdo temático e o estilo de quem o produz. Em outros termos, o gênero meme possui uma estrutura relativamente estável (fotos, gifs, frases, imagens, etc.), a qual denominamos estrutura composicional; trata e/ou refere-se sempre a um tema social que está na ordem do dia, o que compreende o conteúdo temático; por fim, carrega e manifesta, através de uma linguagem humorística, as intencionalidades de um dado enunciador - estilo.

Nessa dimensão, o memes caracteriza-se por um caráter eminentemente interativo, uma vez que os sentidos são produzidos de modo bastante evidente a partir das relações entre os enunciados (porque são relações entre os sujeitos que participam da enunciação, se constituem por ela e a constituem), ao contrário de outros textos em que esse acontecimento ocorre de forma menos explícita. Desse modo, é possível considerar o memes como uma retextualização de outros textos, uma vez que toma como base ideias, imagens, situações. Há sempre uma informação que é a base para a produção de memes e que poderá se transformar em outros textos. (SILVA, 2016). O esquema a seguir apresenta o processo de produção, circulação e recepção dos memes. 


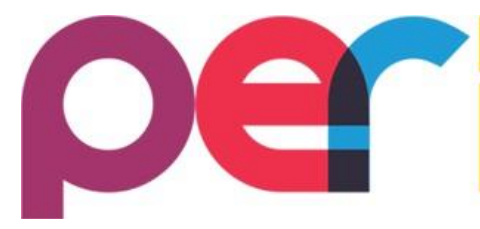

ISSN:1984-9540
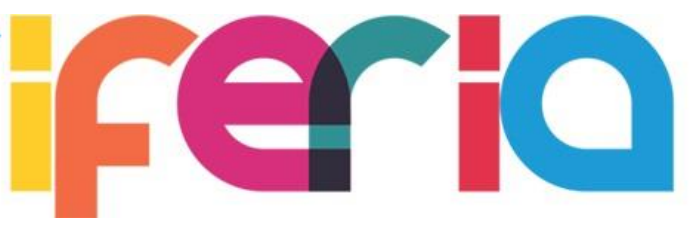

EDUCAÇÃO

CULTURA

\& COMUNICAÇÃO

DOI: $10.12957 /$ periferia.2020.44346

Figura 1: Processo de produção, circulação e recepção dos memes.

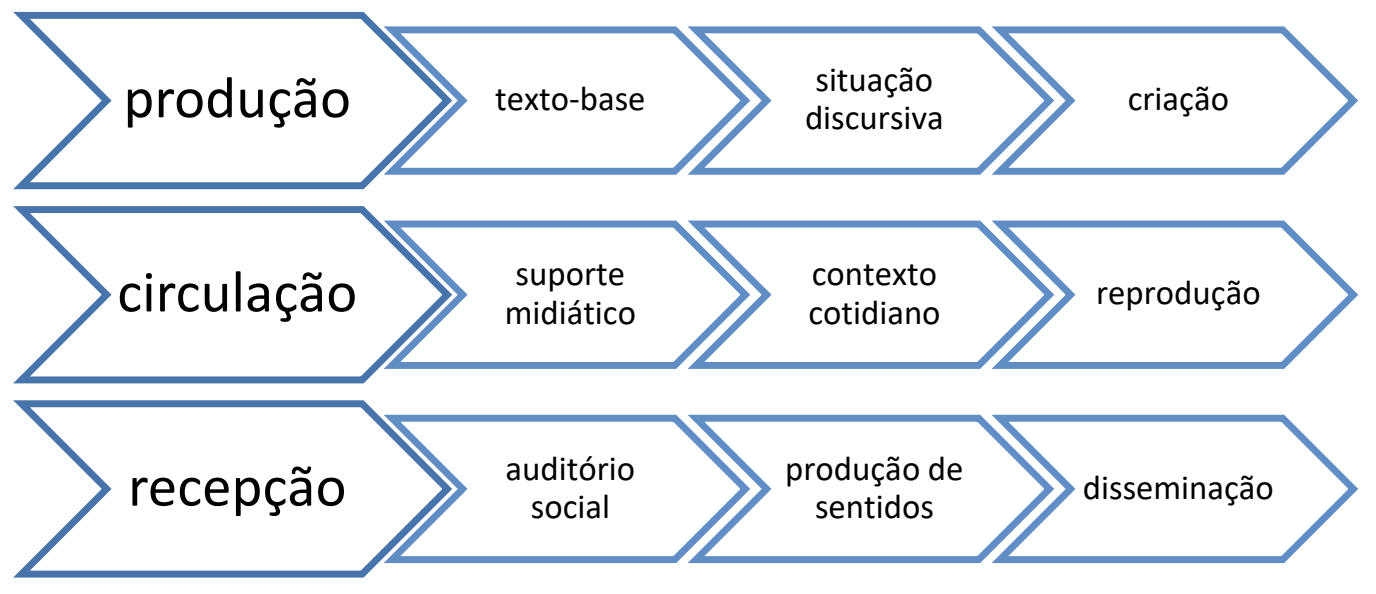

Fonte: Produzido pelo autor

A partir do exposto, é possível considerar o posicionamento de Braga (2018), que pontua que a efetivação do memes, só ocorre a partir do momento que aconteça o contato entre locutor e interlocutor, que produzirá e questionará as diversas significações. Conforme a autora,

o meme surgiu para dar voz a quem deseja expressar suas opiniões, por isso a quantidade de releituras de uma mesma imagem, fato, vídeo, comentário em rede social. Basicamente qualquer expressão, em rede social, é passível de se transformar em meme (s). Esse pensamento expande o que imaginamos por discurso, pois na internet ele pode se organizar de tantas maneiras inesperadas, e a originalidade como se apresenta é uma das premissas para que um meme seja viral. (BRAGA, 2018, p.46)

De acordo com Braga (2018), os memes possuem uma duração e prazo de circulação definidos, segundo a sua natureza temática e discursiva. 0 memes será disseminado enquanto fizer sentido em um contexto discursivo, ou seja, ele continuará com seu tempo de vida ativo desde que ainda abranja questões da época.

Para além dessa questão, é relevante também destacar a questão do estilo de linguagem. Segundo Horta (2015), a multiplicação e a frequente utilização do termo memes na internet, passou a circular e produzir certos significados e expressões de conteúdos surgidos na internet, fazendo com que as pessoas ou usuários do ambiente online, tivessem que possuir certa "formação" ou contextualização sobre os memes, para que a compreensão deles fosse efetiva. Dessa forma, surgiu a possibilidade de 


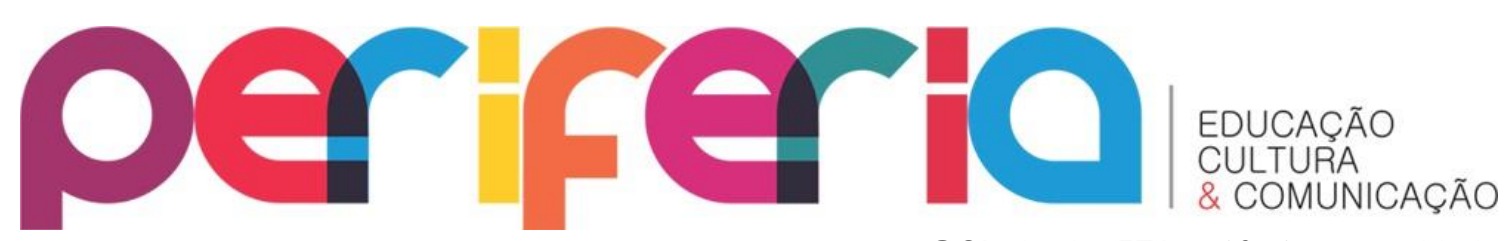

ISSN:1984-9540

DOI: $10.12957 /$ periferia.2020.44346

se pensar em uma linguagem utilizada para compreensão dos memes, formando uma maneira singular de se perceber o mundo.

A presença do meio de comunicação na definição do meme pelos usuários, isto é, tratar as diversas manifestações que surgiam como meme(s) da internet, também nos propôs uma reflexão acerca do impacto do próprio meio no fenômeno que nele surgia, nos conduzindo a um questionamento complementar à hipótese de o meme ser uma linguagem: poderíamos pensar em uma linguagem da internet? Questão que emerge também da observação da ideia de linguagem associada a outros meios e técnicas, como "linguagem televisiva", "linguagem cinematográfica", "linguagem fotográfica”. (HORTA, 2015, p.47)

A reflexão de Horta (2015) suscita a existência de um estilo de linguagem própria dos memes, que é explicitado por XXX e Villarta-Neder (2017, p. 70):

estudar a linguagem em seus aspectos semióticos é considerar as escolhas e as combinações sígnicas e suas formas de organização para direcionar sentidos e para evocar interpretações. Nesse sentido, as expressões faciais, postura corporal, atitudes, cores, movimentos, sons, palavras, imagens, diagramação, planos, enquadramentos, saliência, design etc., sinalizam possibilidades interpretativas. Nessa concepção, os textos são considerados como um sistema de signos verbais e não verbais, que se organizam nas dimensões linguísticosemióticas e discursivas. Essa configuração demanda do leitor novas habilidades para a depreensão dos elementos e das combinações sígnicas que participam do processo de produção dos sentidos. Assim, os memes oferecem possibilidades para uma análise das multissemioses, em uma perspectiva enunciativa, já que os recursos semióticos e os interlocutores (enunciador e enunciatário) se configuram também como signos da textualidade, uma vez que integram o circuito de produção, circulação e recepção.

Dessa forma, os internautas em geral que estão em contato com os memes necessitam adquirir uma série de competências atreladas a compreensão dos elementos presentes nas diferentes linguagens presentes no gênero memes, para que a partir disso enriqueçam a produção de sentidos.

Com vistas a sintetizar as características do gênero memes, apresentamos, a seguir, uma proposta, a partir de uma configuração de quadro-síntese, com base nos estudos de Santos (2013), com os principais traços característicos do gênero memes. 


\section{oer}

ISSN:1984-9540

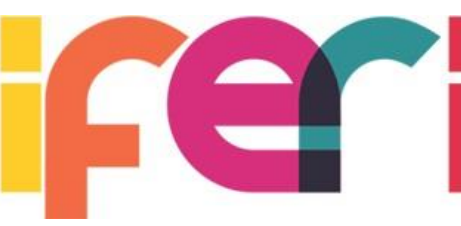

Traços característicos

CULTURA

\& COMUNICAÇÃO

DOI: $10.12957 /$ periferia.2020.44346

Gênero discursivo

\begin{tabular}{l}
\hline Nome específico \\
\begin{tabular}{|l|l|}
\hline $\begin{array}{l}\text { 1) Contexto de produção, recepção e } \\
\text { circulação. } \\
\text { a) Autor } \\
\text { b) Leitor previsto } \\
\text { c) Suporte (material físico que carrega o } \\
\text { gênero) } \\
\text { d) Domínio discursivo }\end{array}$ & $\begin{array}{l}\text { a) Internautas em geral } \\
\text { b) Internautas em geral } \\
\text { c) Internet, computadores, celulares, tablets. } \\
\text { d) Eletrônico/ digital }\end{array}$ \\
\hline 2) Tema// conteúdo & $\begin{array}{l}\text { Entretenimento, crítica política, interação entre } \\
\text { amigos, cultura, economia, entre outros. }\end{array}$ \\
\hline 3) Função/ objetivo & $\begin{array}{l}\text { Imitar pessoas, animais, e outros entes com a } \\
\text { intenção de fazer humor, ironia, crítica, } \\
\text { demonstrar de criatividade, entre outros. }\end{array}$ \\
\hline 4) Organização básica/ estrutura & $\begin{array}{l}\text { Normalmente o meme é composto por uma } \\
\text { fotografia chamativa, colorida ou em preto e } \\
\text { branco, como primeiro plano. Pode conter ou não } \\
\text { enunciados/frase na parte superior ou inferior. }\end{array}$ \\
\hline 5) Linguagem adequada/ estilo & $\begin{array}{l}\text { Apresenta linguagem mista, predominando a } \\
\text { escrita informal, concisa. }\end{array}$ \\
\hline
\end{tabular}
\end{tabular}

Fonte: Elaboração dos autores, com base nos teóricos citados e nas características dos meme(s).

\section{0 trabalho com o gênero memes em sala de aula}

As novas tecnologias da informação e da comunicação intensificaram a circulação de textos multissemióticos, ou seja, textos que combinam imagens em movimento, imagem de figura fotográfica, vídeo, música, palavras, cores, diagramações, ou qualquer elemento que contribua para a construção de um conteúdo irônico ou humorístico que se replique entre vários internautas. (SANTOS, 2015).

O contexto de produção, a mensagem verbal e os elementos imagéticos que compõem o gênero memes apresentam-se de modo articulado, permitindo ao leitor a identificação do objetivo comunicativo subjacente ao texto (entretenimento, crítica política, interação entre amigos, manutenção de contato, etc.). Assim, incluir, mais precisamente o gênero memes em movimento nas aulas de língua portuguesa, com os quais os discentes têm contato em seus momentos de entretenimento/ interação, permite que eles reflitam sobre as interações que realizam fora do espaço escolar. Trazer para a sala de aula textos que circulam no cotidiano, pode representar uma possibilidade para motivar os alunos para realizar análises linguísticas, semióticas e discursivas, visto que, recorrentemente, atividades 

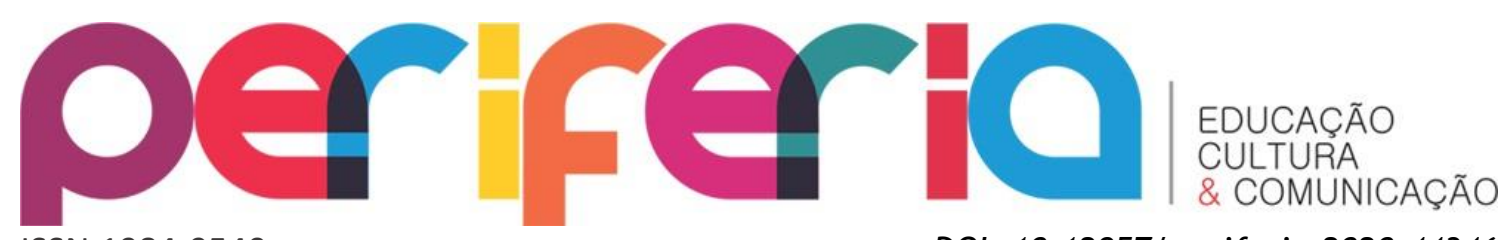

DOI: $10.12957 /$ periferia. 2020.44346

dão extrema primazia à modalidade escrita, o que pode tornar as aulas extremamente exaustivas e desinteressantes, porque não ocorre uma identificação desses alunos com tais atividades. (BRAGA, 2018)

A autora faz uma advertência para a possibilidade de disseminação de produções de cunho preconceituoso e ofensivo. Os discentes compartilham esses memes, espalhando esses conteúdos negativos e não se dando contas de como essas postagens podem ser prejudiciais para o seu desenvolvimento pessoal e humano (BRAGA, 2018). Dessa forma, a abordagem dos memes em sala, pode ser uma forma enriquecedora também pelo potencial formativo.

Nessa direção, merece destaque a potencialidade dos memes para uma reflexão sobre os processos de interação entre amigos/ manutenção de contatos. Nesse sentido, é possível ponderar sobre a adequação de compartilhamento via redes sociais. Nesse processo, é preciso considerar o perfil do interlocutor, o grau de intimidade, a situação sociodiscursiva, o conteúdo temático, a abordagem dada às informações, a pertinência das imagens etc. Produzir e disseminar memes pode ser um incentivo à criatividade, à interação, ao entretenimento, à leitura crítica das questões sociais. De acordo com Silva, (2016, p.26), "o trabalho com memes contribui para diversos fatores, uma vez que enriquece a compreensão de contexto, compreensão de formas de uso da escrita (como a ironia) e adaptação à imagem".

Além disso, merece destaque nos memes como a segunda das potencialidades aqui elencadas, a intertextualidade que "nasce de um diálogo entre vozes, entre consciências ou entre discursos, como uma multiplicidade que se relaciona sem o intuito de anulação, mas sim de compartilhamento para algo além das mesmas, para gerar novos discursos." (ZANI, 2003, p. 125)

Dessa forma, observa-se que a intertextualidade está de fato presente nos memes, pois no momento em que ele é produzido, o seu produtor utiliza de recursos semióticos e conteúdos existentes em outros textos, que foram criados anteriormente e que agora tomam uma nova forma. Ao passo que um texto é utilizado como referência em outras construções, ele irá dar origem a outro memes que circulará estabelecendo um novo sentido, e assim possibilitará um maior tempo de vida do memes, ocasionando em um maior alcance de pessoas. A compreensão do fenômeno da intertextualidade poderá ser facilitada a partir da leitura de memes, 

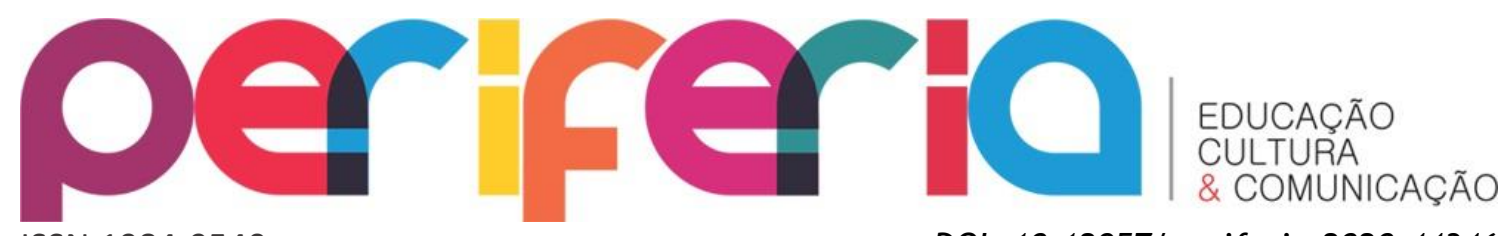

ISSN:1984-9540

DOI: 10.12957/periferia.2020.44346

por ser uma maneira familiar e, muitas vezes, divertida de se compreender como

cada texto possui informações que o antecedem, advindos de outros textos que um dia surgiram de produções anteriores e que no futuro resultarão em composições novas.

Além da intertextualidade, constatamos como a quarta potencialidade dos memes o favorecimento dos processos de leitura de textos multissemióticos. À vista disso, entendemos que "a comunicação não é somente a linguagem verbal, ela é feita em grande parte pela linguagem não verbal. 0 importante é que uma esteja em concordância com a outra, de forma que a comunicação seja um processo completo e coerente" (SCHELLES, 2008, s/p.). Embora os textos multissemióticos ${ }^{5}$ estejam presentes em várias práticas sociais, eles ainda não recebem a devida atenção dentro do âmbito escolar. Esses textos contribuem para uma nova forma de letramento: o visual, não apenas analisar a estrutura interna das imagens, mas no caso do memes analisar seus enquadramentos, seleção de cores, tamanho das letras entre outros aspectos - esses são itens que precisam ser lidos e analisados.

De acordo com Silva (2018, p.21),

As práticas de ensino de língua materna devem propiciar o desenvolvimento de estratégias para leitura de múltiplas e conjugadas linguagens, uma vez que o mundo está em constante transmutação, especialmente tecnológica, e obrigando, assim, os indivíduos ao enquadramento nessas mudanças, para estarem aptos para o convívio social, visto que a sociedade está impregnada de semioses interativas. Ser leitor desperto é um fator relevante para a formação crítica do estudante, visto que ele precisa desenvolver a capacidade de refletir sobre as informações veiculadas na mídia, por exemplo, para posicionar-se criticamente frente a elas, associando-a ao seu contexto sociocultural.

Ao considerar os memes como ferramenta importante nas aulas de Língua Portuguesa, é relevante destacar que,

diante dos avanços tecnológicos e das possibilidades criadas cotidianamente pelos meios digitais disponíveis para se estabelecer a comunicação, faz-se urgente perceber os nossos educandos como atores protagonistas na coconstrução de saberes significativos, reconhecendo o lugar que eles ocupam como produtores de conhecimento em novas mídias. (SOUZA, 2014, p.1477).

\footnotetext{
${ }^{5}$ Os textos multimodais ou multissemióticos são os que apresentam em sua constituição diferentes elementos, como por exemplo, cor, movimento, música, tamanho da letra, vídeo, signos icônicos. (CARMELINO, 2015, p.22).
} 


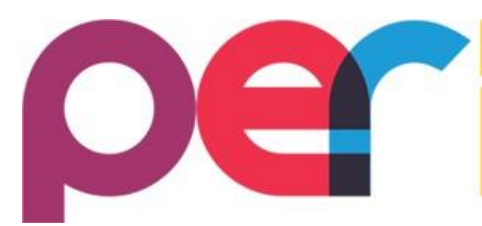

ISSN:1984-9540

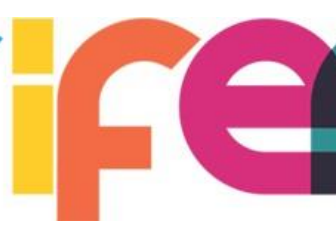

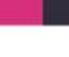

A partir desses pressupostos de que o aluno necessita estar na posição de sujeito da aprendizagem e realizar suas próprias construções, torna-se indispensável considerar como a quarta das potencialidades aqui elencadas, a produção de memes como uma ferramenta importante para o trabalho com as múltiplas linguagens em sala de aula, pois os memes são, de forma geral, um dos gêneros que mais atraem as pessoas para as redes sociais e para a internet no cotidiano social. Baseando-se nessas considerações, a produção de memes em sala de aula poderá consolidar nos alunos vários conhecimentos que estão previstos no currículo escolar, tanto no que se refere ao domínio de habilidades linguístico-semiótico-discursivas, quanto no que se refere ao domínio de habilidades relacionadas aos letramentos multissemióticos.

\section{Análise de memes em movimento}

Além da pesquisa teórica sobre o gênero memes e seu ensino, este trabalho se compõe pela socialização de uma análise de memes produzidos por licenciandos do Curso de Letras, de uma Universidade Pública, na cidade de Lavras - MG, no ano de 2019 no âmbito de um minicurso proposto para participantes do Programa institucional de bolsas de iniciação à docência. A preparação para a realização da coleta de dados aconteceu da seguinte forma: de início, foram realizadas discussões no âmbito do PIBID (Programa Institucional de Bolsas de Iniciação à Docência), ligadas à relevância social do gênero meme e suas características linguísticosemiótico-discursivas e das possibilidades de trabalho no contexto da escola, dado o contexto de discussões sobre questões ligadas aos gêneros multissemióticos. Posteriormente, como proposta de produção, os estudantes/bolsistas elaboraram um meme em movimento, com a temática livre, sendo orientados a observar e considerar os aspectos discutidos nas reuniões. Após a produção, os memes em movimento foram submetidos à análise. As análises constituem-se de cunho descritivo-analítico e apresentam uma abordagem qualitativa.

\section{a) Memes: Willy Wonka/ Cena filme "Minha mãe é uma peça"}




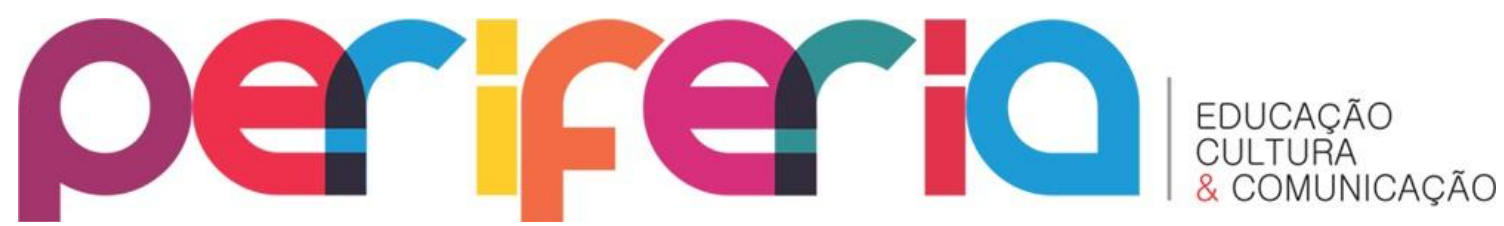

ISSN:1984-9540

DOI: $10.12957 /$ periferia.2020.44346

Ao examinar o conteúdo temático do memes em questão, faz-se necessário contextualizar o personagem, a fim de que haja a compreensão das semioses presentes neste texto. Willy Wonka é dono da fantástica fábrica de chocolates, representado pelo ator Gene Wilder em 1971, ele é um dos personagens principais do filme. A partir dessas informações constatou-se que a imagem do personagem continua a mesma, sem nenhuma alteração, como também o plano de fundo que é utilizado para formar a figura. Consequentemente, na cena a seguir percebeu-se uma versão diferente, que é uma cena do filme Minha mãe é uma peça, e que de certo modo estabelece um sentido com a primeira imagem. A primeira imagem (figura 1) serve como provocação para o desenrolar do enredo: "Conte-me como é levar um banho de água fria na cama". A inserção da imagem com o personagem com uma expressão sarcástica incita o levantamento de hipóteses sobre o desdobramento do enredo. Tendo em vista esses elementos e a análise do plano composicional, a seguir apresenta-se um quadro com as etapas, processos e eventos presentes no memes.

\begin{tabular}{|l|l|l|}
\hline Etapa & Processo & Eventos \\
\hline $\begin{array}{l}\text { Solicitação sarcástica de um } \\
\text { relato }\end{array}$ & $\begin{array}{l}\text { Mobilização do leitor para as cenas } \\
\text { seguintes. }\end{array}$ & $\begin{array}{l}\text { Personagem sentado e } \\
\text { sorrindo }\end{array}$ \\
\hline Relação familiar & A paz é substituída pelo desespero. & $\begin{array}{l}\text { Filha dormindo } \\
\text { Mãe jogando balde de água } \\
\text { Presença de linguagem } \\
\text { mista }\end{array}$ \\
\hline
\end{tabular}
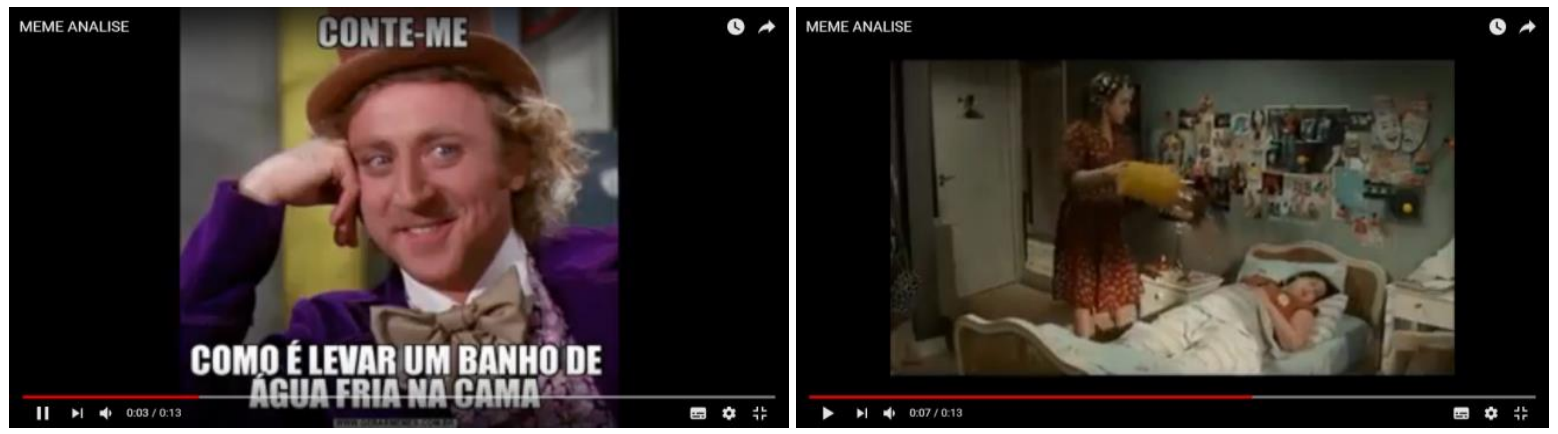

Periferia, v. 12, n. 3, p. 302-321, set./dez. 2020 


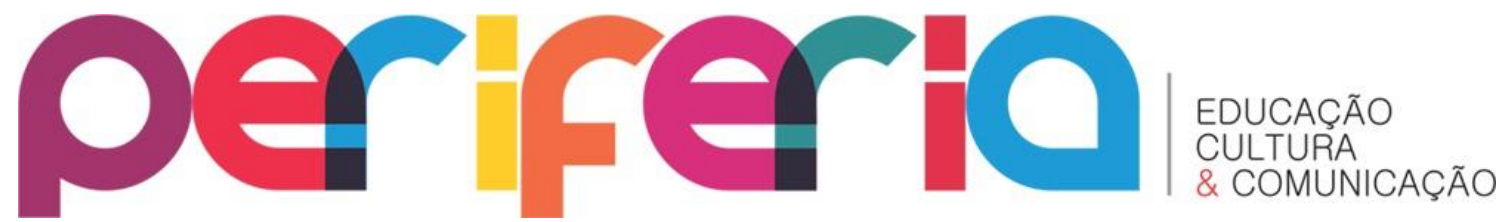

ISSN:1984-9540

DOI: $10.12957 /$ periferia. 2020.44346
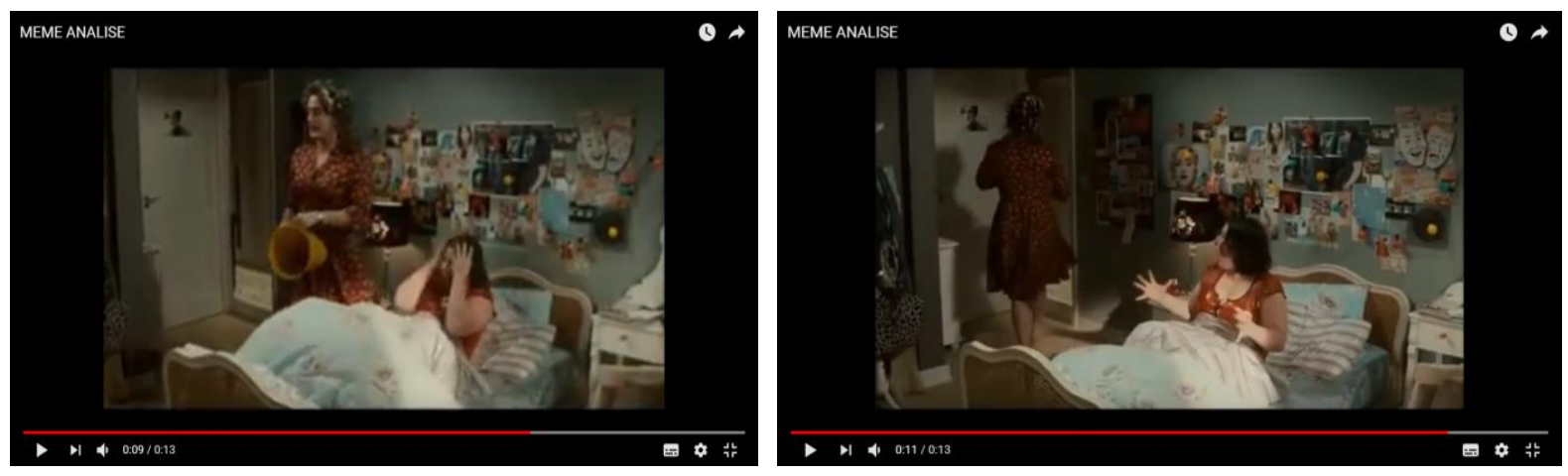

Figura 2: Memes:Willy Wonka/ Cena filme "Minha mãe é uma peça"

Fonte: Disponível em:<

https://www.youtube.com/watch?v=Z_etWMRUrB0\&feature=youtu.be>. Acesso em: 16 de nov. 2014.

No que concerne ao olhar do personagem do filme na cena 1, parece ser possível evidenciar que ele focaliza diretamente para o autor participante do cenário do discurso, e desse modo, o seu olhar estabelece uma interação diretamente com o leitor (VIEIRA, 2015). À vista disso, além, da expressão irônica, a cor da sua camisa revela um mistério sobre o contexto da frase. A cor roxa da sua camisa "representa fantasia, mistério, e mágica e pode gerar um sentimento de imaginação e sabedoria”. (ZYLBERGLEJD, 2017, p. 66).

Vale destacar, nas cenas a seguir, a expressividade demonstrada pela mulher que está na cama e, desse modo, podemos constatar que:

o corpo fala e fala mesmo. Aponta as mentiras, expõe verdades inconscientes, reforça as ideias, dá ênfase à comunicação, favorece ou dificulta o entendimento e promove a interação com emissor e receptor da mensagem. Sendo assim, a linguagem funciona como um meio de manutenção ou criação de relações de poder e controle. (SCHELLES, 2008, s/p.)

Nesse sentido, a partir das cenas em destaque, constata-se que os recursos semióticos também são indiciadores de sentido. As mãos na cabeça da mulher que está na cama, no caso a filha, e as mãos nas pernas indicam, por exemplo, indignação.

Periferia, v. 12, n. 3, p. 302-321, set./dez. 2020 


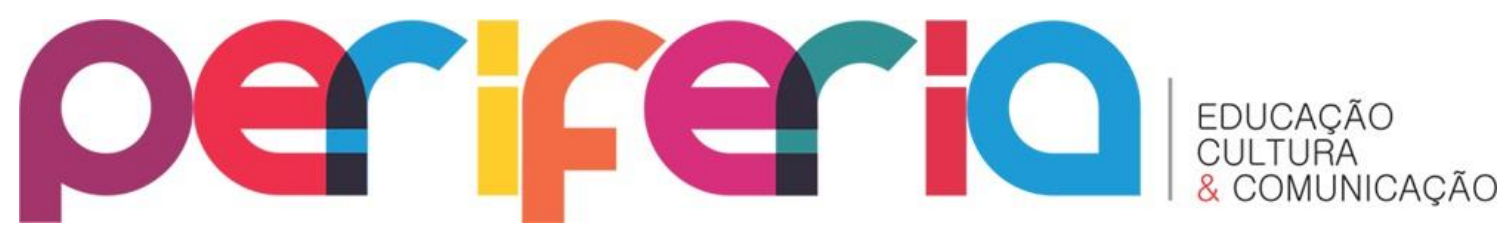

ISSN:1984-9540

DOI: $10.12957 /$ periferia.2020.44346

\section{b) Memes: Perto dos pais/ longe dos pais}

Com relação ao conteúdo temático, identifica-se nesse memes a reação da mulher ao estar diante dos pais e como ela realmente é diante dos amigos. Para além disso, com relação ao plano composicional, a seguir apresenta-se um quadro tendo em vista a estrutura e composição do memes.

\begin{tabular}{|l|c|l|}
\hline \multicolumn{1}{|c|}{ Etapas } & \multicolumn{1}{|c|}{ Processos } & \multicolumn{1}{c|}{ Eventos } \\
\hline $\begin{array}{l}\text { A mulher relatando como ela } \\
\text { fica perto dos pais. }\end{array}$ & Dócil/Comportada & $\begin{array}{l}\text { Personagem } \\
\text { docilmente. }\end{array}$ \\
\hline $\begin{array}{l}\text { A mulher revelando como ela } \\
\text { realmente é. }\end{array}$ & Extrovertida/ Desinibida & $\begin{array}{l}\text { Personagem consumindo } \\
\text { bebida alcoólica com os } \\
\text { amigos. }\end{array}$ \\
\hline
\end{tabular}
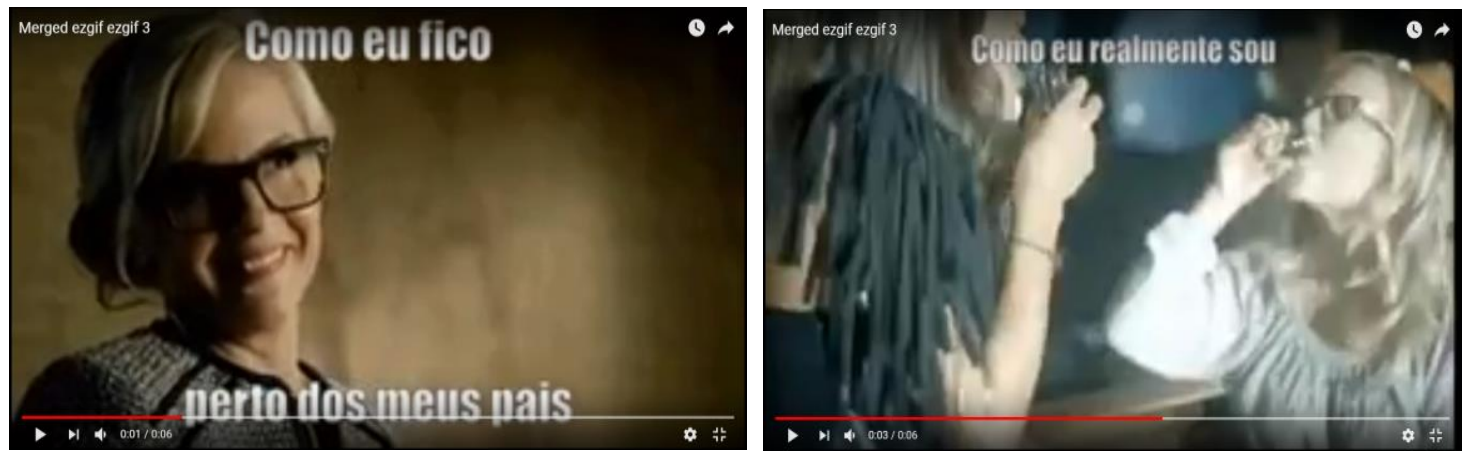

Figura 3: Memes:Perto dos pais/ longe dos pais

Fonte: Disponível em: <https://youtu.be/VxYwpjbYC1l>. Acesso em: 16 de nov. 2014.

Ao analisar o memes em questão, é relevante partir da afirmação de Vieira (2015, p. 45) que postula que,

Para levar a efeito a análise multimodal, é necessário que tratemos dos modos semióticos, que descrevem como as semioses podem representar a verdade do mundo real; como as imagens constroem a realidade; como elas recortam o mundo e como intencionalmente podem omitir detalhes.

A partir dessa perspectiva, merecem destaque os elementos visuais, como a imagem em movimento utilizadas nesse memes. Na construção da primeira cena, a mulher apresenta uma aparência de bom comportamento, com cabelos presos, de óculos (típica intelectual), com uma vestimenta aparentemente formal. No momento em que ela aparece longe dos pais, os cabelos estão soltos, a blusa mais casual e ocorre a ingestão de bebidas supostamente alcóolicas, o que indicia uma ideia de liberdade pessoal. Além disso, segundo Kress e Van Leeuween (2006), a posição 


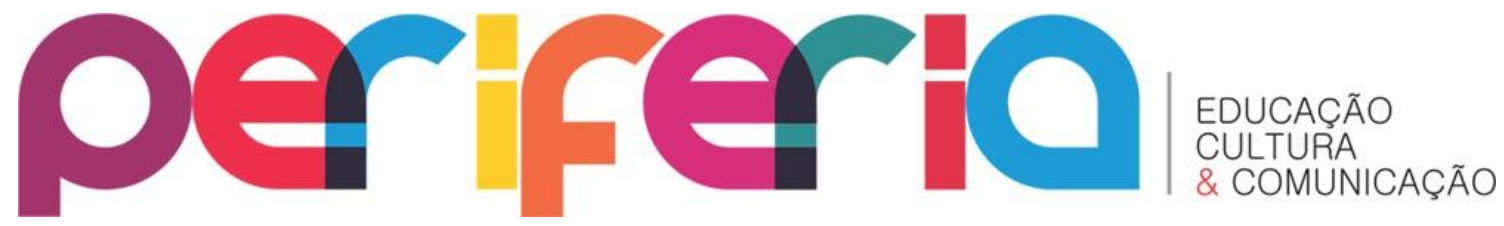

ISSN:1984-9540

DOI: $10.12957 /$ periferia.2020.44346

ocupada pela personagem na cena também indicia sentidos. Nesse sentido, a posição da moça na primeira imagem desvela uma informação de menor importância temática, porque ela está à esquerda da imagem, em detrimento da segunda imagem em que a moça aparece do lado direito, o que evidencia, na cultura ocidental, uma relevância informacional.

À vista dessas reflexões, a construção de sentido deve ser a resposta de um princípio que integra diversos recursos semióticos, considerando que todos os recursos utilizados devem produzir significados visando a um sentido global (VIEIRA, 2015).

\section{c) Memes: Encontro com o CRUSH}

Com relação à organização do terceiro memes, constata-se que ele se organiza em duas partes: a primeira, comemoração por um suposto encontro com o "crush" ${ }^{6} \mathrm{e}$ a segunda, demonstração de decepção pelo cancelamento do encontro marcado.

\begin{tabular}{|l|c|c|}
\hline \multicolumn{1}{|c|}{ Etapas } & Processo & Eventos \\
\hline $\begin{array}{l}\text { A menina relatando que } \\
\text { marcou encontro com o crush. }\end{array}$ & Empolgada & Dançando \\
\hline $\begin{array}{l}\text { O crush desmarca o encontro } \\
\text { em cima da hora }\end{array}$ & Insatisfeita/Enfurecida & Batendo o chinelo na mão \\
\hline
\end{tabular}

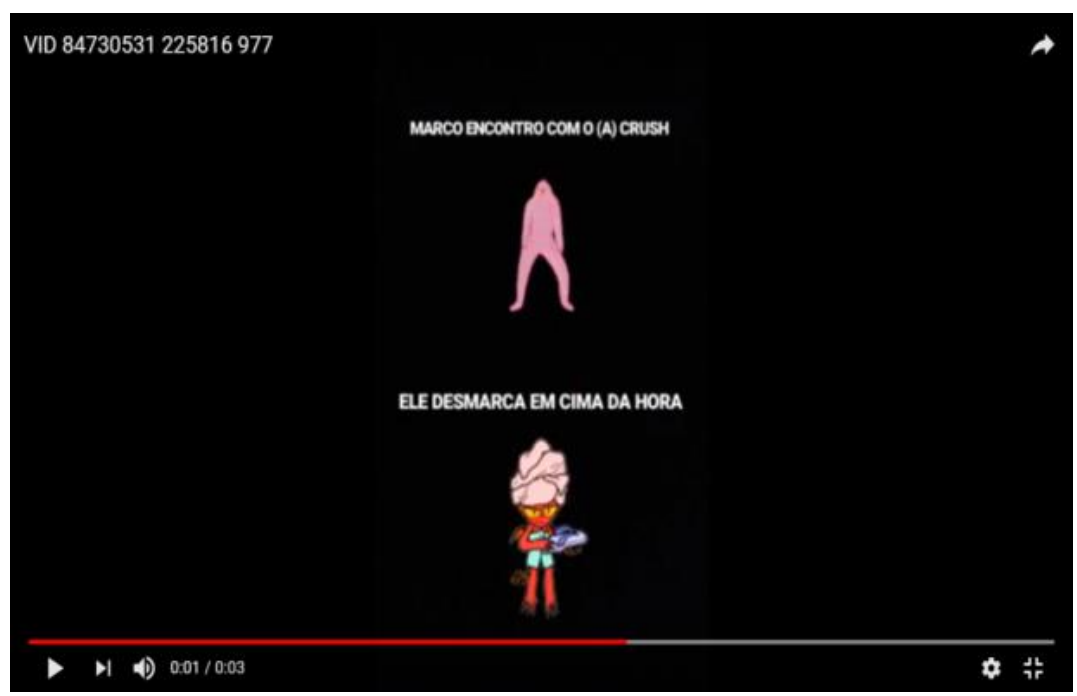

Figura 4: Memes: Encontro com o CRUSH

${ }^{6}$ Crush é um termo da língua inglesa que significa "esmagamento" ou "colisão", na tradução literal para o idioma português. No entanto, esta palavra é normalmente utilizada, pelos adolescentes, no sentido figurado, se referindo a um sentimento de intensa paixão por alguém.

Periferia, v. 12, n. 3, p. 302-321, set./dez. 2020 


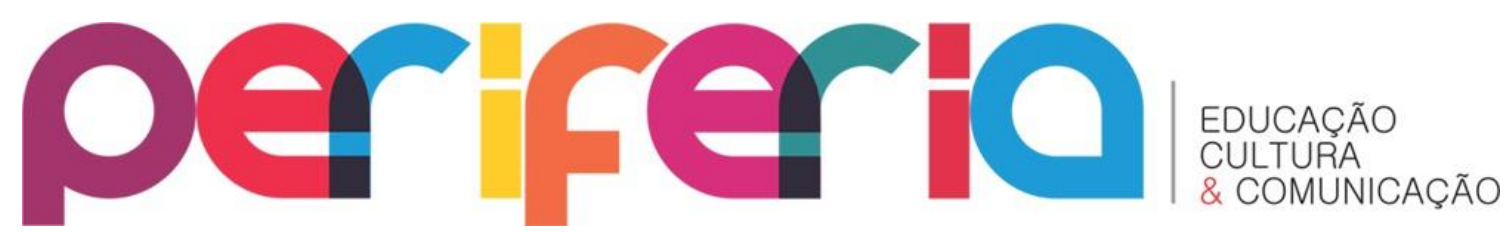

ISSN:1984-9540

DOI: $10.12957 /$ periferia.2020.44346

Fonte: Disponível em:<

https://www.youtube.com/watch?v=4bEEU8XUBtg\&feature=youtu.be>. Acesso em: 16 de nov. 2014.

No que diz respeito aos elementos presentes no terceiro memes, é possível observar a cor predominante na primeira "figura", como um dos elementos a serem analisados, tem-se a cor rosa, que é diretamente associada à imagem feminina (GUIMARAES, 2006). Embora o texto verbal indique a possibilidade de alternância de gênero (o/a), na segunda parte, essa possibilidade é ignorada (por causa do emprego do pronome ele). Diante disso, o discurso é associado a um enunciatário do sexo feminino, que aparentemente demonstra contentamento pelo encontro. Entretanto, em um segundo momento é perceptível que o fato do “crush" ter desmarcado o encontro, a deixou bastante irritada, com a expressão do rosto enfurecida e com a pele agora já na tonalidade vermelha, o que torna possível relacionar ao momento de raiva e decepção amorosa, considerando que a cor vermelha é vista como a cor de diversas paixões desde o amor até o ódio (ZYLBERGLEJD, 2017).

Pode-se perceber que o movimento no meme analisado indicia sentidos que mobilizam a atenção do leitor. A dança e a remissão ao sentido de bater com o chinelo na mão implicam uma relação intertextual, que mobiliza um conhecimento prévio relacionado a um sentimento de satisfação e de indignação/nervosismo.

Sendo assim, as análises dos elementos presentes nos memes, possibilitam a percepção das potencialidades elencadas anteriormente, como a inteiração entre amigos por meio das temáticas comuns entre os jovens, a intertextualidade presente nos diálogos entre textos para a produção de sentidos, a leitura de textos e elementos multissemióticos como os movimentos, cores e sua relevância nos memes, e por fim a produção de memes em sala que engloba o trabalho com as potencialidades elencadas e com diversas outras possíveis.

\section{CONSIDERAÇÕES FINAIS}

O presente trabalho procurou analisar memes em movimento produzidos por alunos de licenciatura, com vistas a provocar uma reflexão acerca das 


\section{periferio}

ISSN:1984-9540

DOI: $10.12957 /$ periferia.2020.44346

potencialidades desse gênero para o processo de ensino-aprendizagem de língua portuguesa. Primeiramente, buscou-se explanar sobre o surgimento dos memes, assim como explicitar suas principais características.

Além disso, buscou-se destacar a relevância do uso dos memes em sala de aula como objeto de ensino, levando em conta que esse gênero é bastante recorrente no cotidiano social e na realidade de pessoas de diferentes classes sociais.

Nesse viés, o trabalho apontou algumas potencialidades dos memes em aulas de Língua Portuguesa. Nesse sentido, merecem destaque a mobilização de interesse do aluno, o estudo das relações intertextuais, a análise das estratégias de humor, o trabalho com as múltiplas semioses.

Além disso, o trabalho buscou apresentar uma análise de três memes produzidos por alunos de um curso de licenciatura, que, após a discussão das características e das funcionalidades desse gênero, deveriam produzir textos que explorassem aspectos como o conteúdo temático, plano composicional e estilo de linguagem. Assim, a produção de memes em movimento representou uma oportunidade de exploração das possibilidades de indiciamentos de sentidos propiciados pelas diferentes semioses.

Desse modo, espera-se que as discussões empreendidas por este trabalho possam contribuir para a compreensão dos processos de organização e de funcionamento do gênero discursivo meme e para a percepção das potencialidades desse gênero para a ampliação de habilidades relacionadas aos multiletramentos, perspectivadas em uma abordagem dialógica, ou seja, como parte de um processo que se estabelece na interação verbal e não verbal e que não limita à materialidade dos textos. Sendo assim, o trabalho com textos em sala de aula poderá assumir um direcionamento pautado em uma resposta ativa, que permita ao aluno analisar, do ponto de vista linguístico-semiótico-discursivo, diferentes gêneros que circulam na sociedade da informação.

\section{REFERÊNCIAS}

BAKHTIN, Mikhail. Estética de criação verbal. 4. ed. Trad. de Paulo Bezerra. São Paulo: 


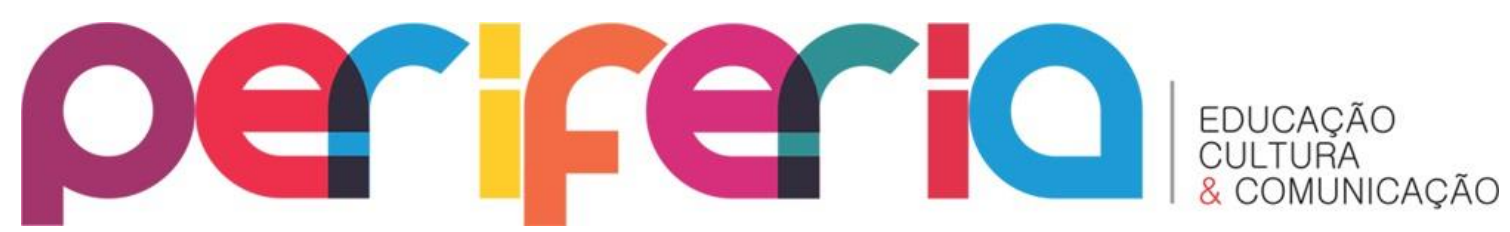

ISSN:1984-9540

DOI: 10.12957/periferia.2020.44346

M. Fontes, 2003.

BAKHTIN, Mikhail. Marxismo e filosofia da linguagem. 7. ed. Tradução M. Lahud e Y. F. Vieira. São Paulo: Hucitec, 1981.

BRAGA, Betânia. Um protótipo didático para o multiletramento com gênero meme para um nono ano. 2018. Dissertação (Mestrado Profissional em Letras) - Profletras, Universidade Estadual de Maringá, 2018.

DAWKINS, Richard. O gene egoísta. São Paulo: Companhia das Letras, 2007.

FERREIRA, Helena; VILLARTA-NEDDER, Marco. Textualização e Enunciação em texto multimodal: Análise do vídeo de animação escolhas da vida, Revista Prolíngua, 2017.

GUERREIRO, Anderson; SOARES, Neiva Maria Machado. Os memes vão além do humor: uma leitura multimodal para a construção de sentidos. Texto Digital, v. 12, n. 2, p. 185-208, 2016.

GUIMARAES, Luciano. O repertório dinâmico das cores na mídia: produção de sentido no jornalismo visual. Revista Compós (trabalho apresentado no Grupo de Trabalho-Produção de sentido nas mídiasll, do XV Encontro da Compós, na Unesp, SP, em julho de 2006), 2006.

HORTA, Natália Botelho. O meme como linguagem da internet: uma perspectiva semiótica. 2015. Tese de Doutorado. Dissertação de mestrado, UNB, Brasília, Portugal. Retirado de http://repositorio. unb. br/bitstream/10482/18420/1/2015_ NataliaBotelhoHorta. pdf.

KRESS, G.; VAN LEEUWEN, T. Reading images: the grammar of visual design. London: Routledge, 2006.

RECUERO, R. C. Memes em weblogs: proposta de uma taxonomia. Conexões nas Redes Midiáticas. Revista FAMECOS, Porto Alegre, n. 32, p. 23-31, abr. 2007.

SANTOS, A. M. O estudo de memes no ensino da língua. 2015. Dissertação (Mestrado Profissional em Linguística Aplicada) - Universidade Federal de Sergipe, Itabaiana.

SCHELLES, Suraia. A importância da linguagem não-verbal nas relações de liderança nas organizações. Revista Esfera, v. 1, n. 1, 2008.

SANTOS, G. J. F. Elementos de argumentação na produção de gêneros textuais no Ensino Médio. 2013. Tese (Doutorado em Estudos da Linguagem) - Universidade Estadual de Londrina, Londrina, PR. 2013.

SILVA, Luciana Idalgo da et al. $O$ uso do Facebook no contexto escolar: os gêneros meme e fotopoema para a produção textual em língua inglesa. 2016. Dissertação de Mestrado- Universidade Tecnológica Federal do Paraná, 2016.

SILVA, Zenilda Rodrigues. O gênero meme da Internet: dialogismo e semiótica na construção

Periferia, v. 12 , n. 3, p. 302-321, set./dez. 2020 


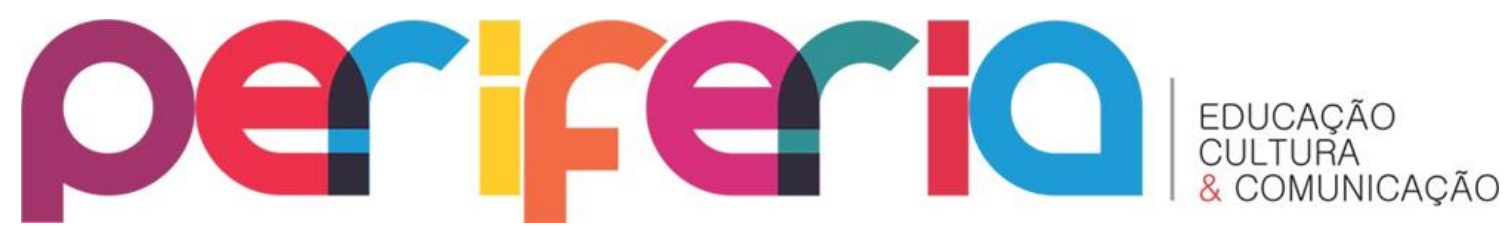

ISSN:1984-9540

DOI: 10.12957/periferia.2020.44346

textual. 2018. Dissertação (Mestrado profissional) - Profletras, Universidade Estadual de Montes Claros, 2018.

SOUZA, Carlos Fabiano. Memes em aulas de português no ensino médio: Linguagem, produção e replicação na cibercultura. Revista Philologus, Ano 20, $\mathrm{N}^{\circ} 60$ Supl. 1: Anais da IX JNLFLP. Rio de Janeiro: CiFEFiL, set./dez,2014.

VIEIRA, Josenia; SILVESTRE, CARMINDA. Introdução à Multimodalidade: Contribuições da Gramática Sistêmico-Funcional, Análise de Discurso Crítica, Semiótica Social. Brasília, DF: J. Antunes Vieira, 2015.

ZANI, Ricardo. Intertextualidade: considerações em torno do dialogismo. Em questão, v. 9, n. 1, p. 121-132, 2003.

ZYLBERGLEJD, Raissa. A influência das cores nas decisões dos consumidores. - Rio de. Janeiro: UFRJ/Escola Politécnica, 2017. 